\title{
The active tectonics of the Vuoksi Fault Zone in the Karelian Isthmus: parameters of paleo- earthquakes estimated from bedrock and soft- sediment deformation features
}

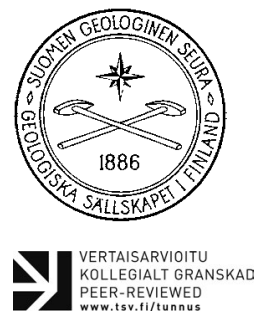

KOLLEGIALT GRAN
PEER-REVIEWED
www.

\author{
Sergey V. ShVAREV ${ }^{\mathrm{I}, 2^{*}}$, Andrey A. Nikonov ${ }^{2}$, \\ Michail V. Rodkin 3,4 ANd Anton V. PoleshchuK ${ }^{5}$ \\ ${ }^{1}$ Institute of Geography, Russian Academy of Sciences, Staromonetny lane 29, Moscow, \\ 119017, Russia \\ ${ }^{2}$ Schmidt Institute of the Physics of the Earth, Russian Academy of Sciences, Bolshaya \\ Gruzinskaya str., 10-1, Moscow, 123242, Russia \\ ${ }^{3}$ Institute of Theory of Earthquake Prediction and Mathematical Geophysics, \\ Profsoyuznaya str. 84/32, Moscow, 117997, Russia \\ ${ }^{4}$ Institute of Marine Geology and Geophysics Far Eastern Branch, Russian Academy of \\ Science, Nauki street., 1B, Yuzhno-Sakhalinsk, 693022, Russia \\ ${ }^{5}$ Geological Institute, Russian Academy of Sciences, Pyzhevsky lane 7, Moscow, 119017, \\ Russia
}

\begin{abstract}
The area under study is located in the south-eastern periphery of the Fennoscandian crystalline shield. At present this is a tectonically quiet region without large seismic events. But it is well known that in post-glacial time the Fennoscandian shield was an arena of active postglacial tectonics and large earthquakes. The evidence for such events was found in various parts of Fennoscandia. The traces left by some paleoearthquakes show an undisputed character of large post-glacial faults some tens of kilometres long and of a few meters in displacement. However, some other features left by earthquakes are under discussion. Numerous deformations in bedrock and in soft sediments which can be considered as being due to earthquakes were found in the Russian Karelia. Interpretation of some of these deformation structures can lead to different conclusions about their origin, for example, weathering, cryogenic, glacial, and gravitational factors. One possible way to overcome these difficulties is an integrated study of different types of deformations at key sites, comparison of these with each other and with the tectonic features of the region, and the search for common structural and kinematic features. Another problem is the estimation of parameters of paleoearthquakes. This problem includes the determinations of their location, intensities, magnitudes, and age.
\end{abstract}


The key site under study is located in the northern part of the Karelian Isthmus in the re-activated (during post-glacial time) tectonic zone (the Vuoksi Fault Zone), whose signature in the relief is seen in the form of the straight-line valley of the Vuoksi River. We studied different types of post-glacial seismogenic deformations at this locality. There are seismically induced gravitational and vibrational deformations in solid rock, as well as folds and ruptures in loose sediments. The key site of large deformation examined here includes three zones: 1 ) the main zone of deformations or the Central Fractured Massif (CFM); 2) the seismically induced colluvial zone; 3) the outer zone of deformations in loose sediments. We have established that all types of deformations are kinematically similar in the CFM and around it (at distances of a few kilometres). A detailed examination of deformations and their spatial and temporal relationships allows us to distinguish three generations of earthquake-induced deformations: 1) Late Glacial, 2) Early Holocene, and 3) Middle to Late Holocene. We estimate the intensities of the respective earthquakes as I=IX, IX, and VII-VIII. Clearly, the intensities decrease from post-glacial to present time, but the recent level of seismicity is unclear and may be much higher than hypothesized. In addition, the evidence for shear kinematics of the fault shows that earthquakes were not only caused by post-glacial rebound, but also resulted from a different tectonic mechanism possibly related to plate tectonics.

Keywords: Fennoscandian shield, Holocene, paleo-earthquakes, earthquake-induced rock fragmentation, soft-sediment deformations, seismically induced rock-falls

*Corresponding author (e-mail: shvarev@ifz.ru)

Editorial handling: Pertti Sarala (pertti.sarala@gtk.fi)

\section{Introduction}

The late- and post-glacial fragmentation of rocks and the deformation of glacial, lacustrine and alluvial sediments was presumably the cause of large earthquakes as described by researchers for different localities in the western part of the Fennoscandian crystalline shield (Kujansuu, 1964; Lundqvist \& Lagerbäck, 1976; Bungum \& Lindholm, 1997; Kuivamäki et al., 1998; Mörner, 1985, 2003; Mörner et al., 2003; Olesen et al., 1992; Sjöberg, 1994; Lagerbäck \& Sundh, 2008; Kukkonen et al., 2011). Similar studies were carried out for the eastern Fennoscandia, which consists of Russian Karelia, the Kola Peninsula, and the Karelian Isthmus (Lukashov, 1995, 2004; Nikonov \& Zykov, 1996; Zykov, 2001; Nikolaeva, 2006; Nikonov, 2008; 2012; Nikonov et al., 2014;
Nikonov \& Shvarev, 2015; Nikolaeva et al., 2017; Shvarev \& Rodkin, 2018). Some locations of paleoearthquakes are undisputable large post-glacial faults tens of kilometres long with displacements of some meters. However, other locations with presumable evidence for earthquakes are debatable. Another point of view is that these deformations can be interpreted differently as, for example, glacial, gravitational, cryogenic, or weathering.

A reliable evidence of the seismic origin of the deformations can result from an integrated study of different traces left by the earthquakes, comparison of their systematic features, and detection of common tectonic and geologic properties (e.g., structure, kinematics, and texture).

However, the confirmation of the seismic origin is only the first part of the study. The determination of parameters of the paleo-earthquakes is equally 
important. These parameters include the location and orientation of the rupture zones, the direction of the seismic impulse, the number of earthquakes and their ages, the intensities and magnitudes of the events, and the tectonic structure that generated the earthquakes.

The key site discussed in detail in this paper is located close to the Vuoksi River near the settlement of Krasny Sokol (the former Sokkola) and the town of Kamennogorsk (the former Antrea) in the northern part of the Karelian Isthmus (Fig. 1a). The location was noticed in the 19th century by the famous Russian geologist A. A. Inostrantsev, who described it as follows: "...close to the Sokkola village... rocks dissected by cracks, which have the forms of galleries... I've entered inside them easily, because these cracks have been transformed locally to small rooms" (Inostrantsev, 1870, authors' translation from Russian from pages 39-40). We studied the area in 2010-2016, and it is referred to below as the "Inostrantsev Caves" (Nikonov et al., 2011, 2014).

The breakage in bedrock is concentrated in a granite massif of a few hundred $\mathrm{m}^{2}$. Below, the massif is referred to as the Central Fractured Massif (CFM). Intensive breakage and cleavage, displacements of rock have occurred there. Characteristic features of the cracks and block displacements suggests a seismic origin of the deformations. We could determine the directions of seismic impulses and the sequence of events by a careful examination of the deformations. We also studied the colluvial plume, folds, and faulting in the loose deposits around the massif. We have found that gravitational landforms and the soft-sediment deformations are closely interconnected with each other, and are similar in the massif and in the peripheral zone at a distance of a few hundred meters to a few kilometres. The orientations of crevices, the directions of the block displacements, and the movements of boulders in talus, are the same as the orientation and kinematic characteristics of ruptures in unconsolidated post-glacial sediments. There is a systematic agreement between the deformation patterns in bedrock and in loose deposits, similarly to the space parameters of the large fault zone that is found in the strictly oriented valley of the Vuoksi River (the Vuoksi Fault Zone (VFZ)). All these characteristics provide evidence that the gravitational and soft-sediment deformations studied here were also induced by earthquakes, and that the VFZ was responsible for the earthquakes. We examined an alternative genesis of rock and softsediment disturbances, such as an influence of glacial or glaciofluvial, weathering, cryogenic, and gravitational processes, and came to the conclusion that there are specific features in all types of deformation that contradict these assumptions, so that the seismic origin of the deformations seems to be the most reasonable explanation.

We have examined the relative positions of the deformations and ${ }^{14} \mathrm{C}$ dates to infer that three large seismic events of Late Glacial to Holocene time could generate these features. We have estimated the intensities of paleo-earthquakes (using the "ESIscale" (Michetti et al., 2007)), and the possible pairs of values (magnitudes and the hypocenter distance) from our new approach based on evaluations of particle velocities that could cause the observed block displacements (Rodkin et al., 2012).

\section{A geological and geomorphologic description of the area}

The area of study is situated along the southern periphery of the Fennoscandian crystalline shield, which controls a typical two-stage geological structure: the lower stage is composed of basement rocks, and the upper stage is a thin discontinuous cover of last-stage glacial, late- and postglacial deposits with a thickness of less than a few meters in valleys. The area is located in the Lazurnensky Massif that includes Late Karelian granites and gabbroids near its western border with the Early Riphean Vyborg massif that is composed of anorthosites and rapakivi granites. The two massifs are separated by quasi parallel or echelon faults that 
form a wide $(2-4 \mathrm{~km})$ zone striking NW (320$330^{\circ}$ ) and extending for approximately $100 \mathrm{~km}$. These parameters of the zone classify it as an old first order fault zone (Afanasov \& Shuldiner, 1999).

The majority of other regional faults are orientated in the same direction and are related to the Ladoga-Botnia fault zone (Afanasov \& Shuldiner, 1999) (Fig. 1b). All branches of VFZ (as named by the present authors), equally as most other regional faults, were inferred from indirect evidence, mostly geologic unconformities in Precambrian rocks as found by a geological survey. Direct evidence for the faults is very rare, because they occupy low topography locations where they are hidden by the hydrographic network (rivers and lakes) or by loose deposits in depressions. In the case of VFZ, the axes of the faults within it are located under the beds of the Vuoksi River and some quasi parallel lakes. Only a wide zone of cleavage was detected on the bedrock banks of the Vuoksi River. The VFZ origin can be traced back to Proterozoic and Riphean tectonic activity.

The main features of present-day landforms were due to tectonic factors and partly by glacial denudation. Linear rocky ridges with smoothed tops and slopes are located mainly along the NW-SE faults, as also in the direction of movement of the last ice sheet in this area (NW-SE) (Legkova \& Mojaev, 1977). The lowlands located between sub-parallel rocky ridges are filled with glacial and glaciolacustrine sediments. The Quaternary deposits consist of gravel and sand moraine, and fluvio- and limno-glacial deposits of the Late Pleistocene (Fig. 1c). The VFZ is seen in the topography as a straight-line valley of the Vuoksi River without traces of ordinary fluvial activity (such as meanders, alluvial terraces, etc.). The valley has the form of a linear graben in the basement that is partly covered by unconsolidated Quaternary sediments (Fig. 1d). The post-glacial activity of the VFZ is seen in numerous cases of intensive fragmentation of rocks and displacements of rock blocks along the banks of the Vuoksi River (Fig. 1f). Numerous deformations were found in the deposits of several terraces 3-15 meters in relative height.
These deformations consist of tectonic dips in the layers, normal faults with offsets of a few tens of centimetres, clastic dikes, mixed pro-fluvial deposits, and typical "horizons of events" (Shvarev et al., 2017; Subetto et al., 2017). The deformations are abundant in post-glacial deposits, such as glaciofluvial sands, varved clays of Baltic Ice Lake (BIL), and in more recent sands and silt from low terraces.

The present-day landscape structure involves pronounced tectonic features. Narrow elongated hollows divide rocky hills with quasi-vertical scarps. These hollows form chains and networks which reveal the block-fault structure of the area. The "fresh" shapes of some scarps and numerous rock-falls on them allow us to consider the faults that are responsible for the scarps to be re-activated structures.

\subsection{General features of earthquake- induced deformations in the area}

We examined in detail the object "Inostrantsev Caves" where we have found deformation occurring in rocks and loose deposits, in the area around and influenced by VFZ.

Peripheral zone. The investigation of crystalline rock in this zone is impeded by abundant lakes, rivers and late-glacial deposits. Nevertheless, the wide peripheral zone exhibits evident seismogenic disturbances extending from the "Inostrantsev Caves" for more than $10 \mathrm{~km}$ along the valley of the Vuoksi River. Spectacular outcrops of Precambrian rocks are mostly found in the form of scarps along the Vuoksi River system. Here we are focusing on two key sites only. One of these sites, the "Inostrantsev's rocky outcrop", is located 2.7-3.0 $\mathrm{km}$ away from the "Inostrantsev Caves" site in the SW, near the left (eastern) bank of the Vuoksi River (Fig. 1f). Intensive fragmentation of scarps, collapses of big blocks that are partly buried under the slope cover of colluvial deposits, and rock fragments that were dislodged and landed on the terraces were found there. Traces of liquefaction, as well as traces of fall and invasion of mixed clastic 


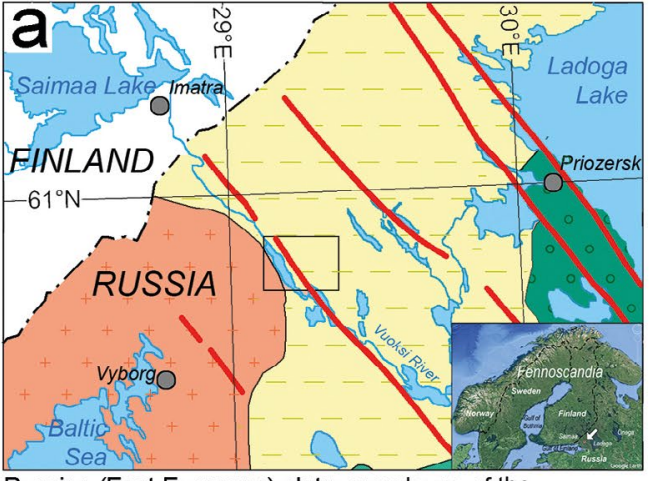

Russian (East-European) plate: complexes of the

$\therefore$ Ediakaran (Vendian) period $\square$ Riphean period Faults of the Ladoga-Botnia zone

$\square$ subvertical faults, defined by geological and assumed by geophysical data

(19) cleavage zones

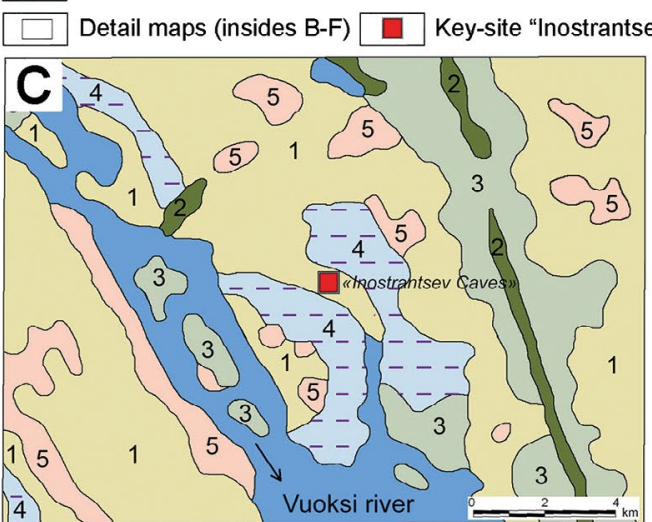

4

Outcrops of bedrock $\square$ Gravel and sand moraine Sand and gravel glacio-fluvial deposits $\square$ Eskers Varved clay and silt deposits

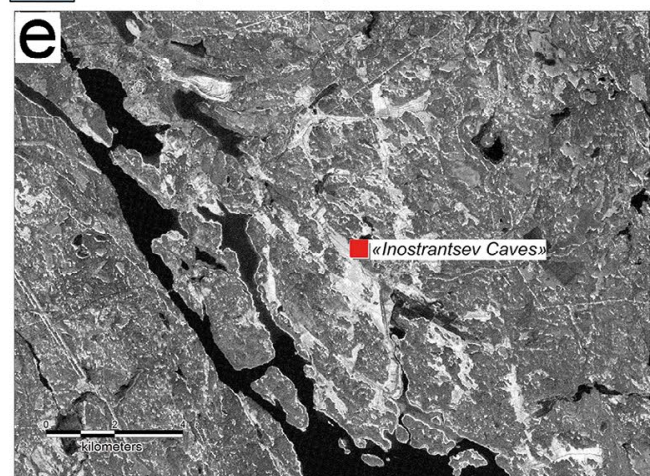

Faults by the geological survey data

$\because$ Master faults $-\longrightarrow$ Secondary faults $\square$ Master faults $\square$ Secondary faults

The town of Kamennogorsk

Outcrops with deformations: 1 - "Inostrantsev R
2 - "Perevoznoje"
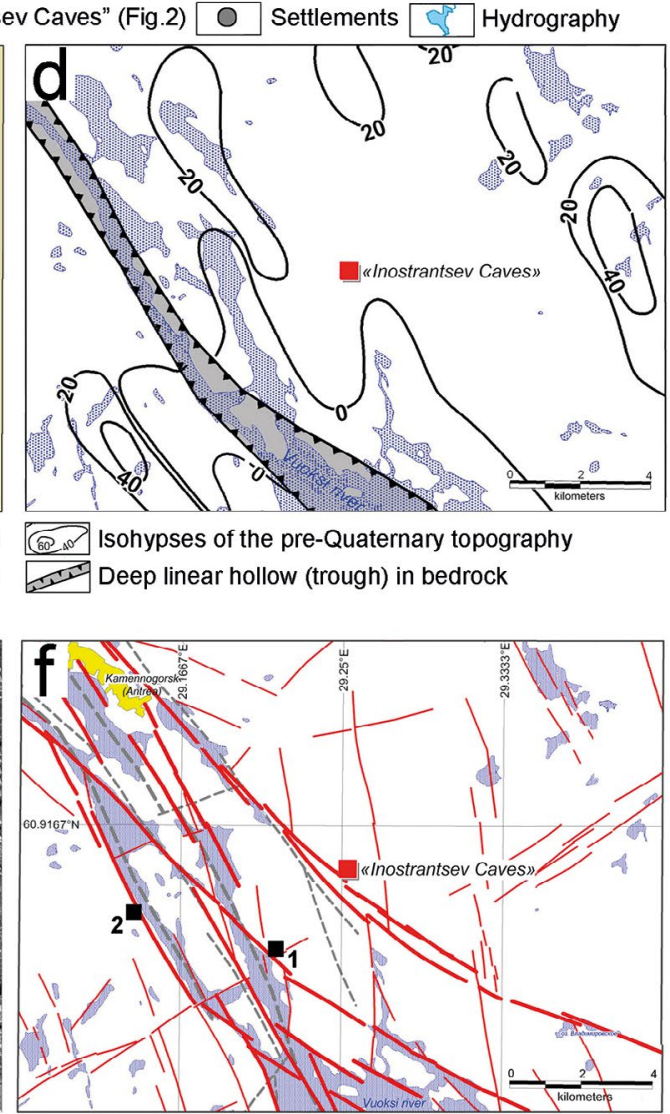

Isohypses of the pre-Quaternary topography

Deep linear hollow (trough) in bedrock

Fennoscandian scheet

Riphean anortosite and rapakivi-granite intrusion

Karelian methamorphic and volcanic rocks

Late Karelian granites and gabbros Early Karelian methamorphic rocks

massif

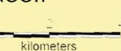


material from the slopes into neighboring Holocene (8-2.5 ka BP) deposits were found there as well (Shvarev et al., 2017; Subetto et al., 2017).

The second key site ("Perevoznoye") is located at a distance of $6 \mathrm{~km}$ from the "Inostrantsev Caves" site, on the right (western) bank of the Vuoksi River 1-2 km downstream from the village of Perevoznoe (Fig. 1f). A site of vigorous dislocations in the rapakivi granite massive was found there in a steep slope with a total height of about $12 \mathrm{~m}$ above the Vuoksi River water level. These dislocations create a system of fractures (gliding) and crevasses (gaping), which are elongated subparallel to the Vuoksi River and dipping towards NE $\left(60^{\circ}\right)$ with a dip of $60^{\circ}$. Apart from this main system, which forms a slope escarpment, a system of curved cracks dipping $70^{\circ}$ at azimuths of $350-360^{\circ}$ is found there. Small-amplitude $(5 \mathrm{~cm})$ shear displacements along the cracks of the first system were identified. Our observations indicate recent reactivation of cracks located in rapakivi granite; the reactivated cracks have left strike-slip kinematics (Nikonov et al., 2014).

We discovered oppositely dipping silt and sand layers in the flanks of the fault zone on both banks of the Vuoksi River. The dips reach $30-35^{\circ}$, probably providing evidence of vertical displacements on the inferred underlying faults (Shvarev et al., 2017; Subetto et al., 2017). These features reflect deformations that occurred here after the existence of the Baltic Ice Lake.

The main zone of post-glacial activation. The main deformation zone is located near the eastern branch of VFZ (Az. 310-320 ${ }^{\circ}$ near its intersection with the secondary $\mathrm{NE}$ (Az. 60 $)$ and NNW (Az. $350^{\circ}$ ) fault systems (Fig. 1f). The ridge-and-hollow topography (short linear ridges separated by troughs) of the site is formed by NW-SE $\left(310-320^{\circ}\right)$ structures (Fig. 2a, ridges 1-4), with subordinate elements of NE-SW $\left(50-60^{\circ}\right)$ orientation (Fig. 2a, ridge 5). All ridges of NW orientation are asymmetric with flat SW slopes and steep NE slopes. The scarps vary in height between 1 and $7-8 \mathrm{~m}$. The cliffs differ in their state of preservation, ranging from those fully smoothed by glacial erosion (NE slopes of the ridges 1 and 2) to vertical walls with fresh cracks (NE slopes of ridges 3 and 4). A transverse SW-NE topographic element is a gently inclined, slightly asymmetrical ridge (5) with a relative height of about $1-2 \mathrm{~m}$. This ridge has a gentle NW slope and a steeper SE slope. The asymmetry of the ridge could have been caused by different processes: the gentle NW slopes and the steep SE slopes could be caused by glacial exaration, while the steep NE slopes appear to be connected with tectonic reactivation in the late-, post-, and probably pre-glacial times.

The site includes three zones of deformation: 1) the CFM, 2) the colluvial plume, and 3) the outer zone of deformation in loose sediments (Nikonov et al., 2011, 2014) (Fig. 2b).

\subsection{The CFM as an area of the most intense rock destruction}

The CFM appears to be the main zone of seismogenic deformation. It is located at the SE edge of the rock ridge elongated in a NW $\left(310-320^{\circ}\right)$ direction. The CFM is broken into large blocks (about 7-9 $\mathrm{m}$ ) by a set of mutually perpendicular sub-vertical or weakly inclined cracks and crevices. The vertical crevices were found to have widths of $10-50 \mathrm{~cm}$ and belong to two main orientations, $310-320^{\circ}$ and $50-60^{\circ}$ (Fig. 2d).

The almost rectangular CFM covers an area of approximately $1000 \mathrm{~m}^{2}$. At its $\mathrm{NE}$ and SE sides, the massif is bounded by near-vertical scarps with heights of $5-7 \mathrm{~m}$. To the SW, the CFM is bounded by a vertical crack, which separates it from the less disturbed part of the ridge. To the NW, the CFM is limited by a zone of collapse which separates it from the undeformed ridge. The collapse zone is adjacent to the CFM on the NW.

The lateral structure of the massif. The CFM has a distinct lateral zoning. We observe differences in the scale of block displacements and in the degree of rock crushing along the ridge. The intensity of destruction increases from SE to NW, starting from 


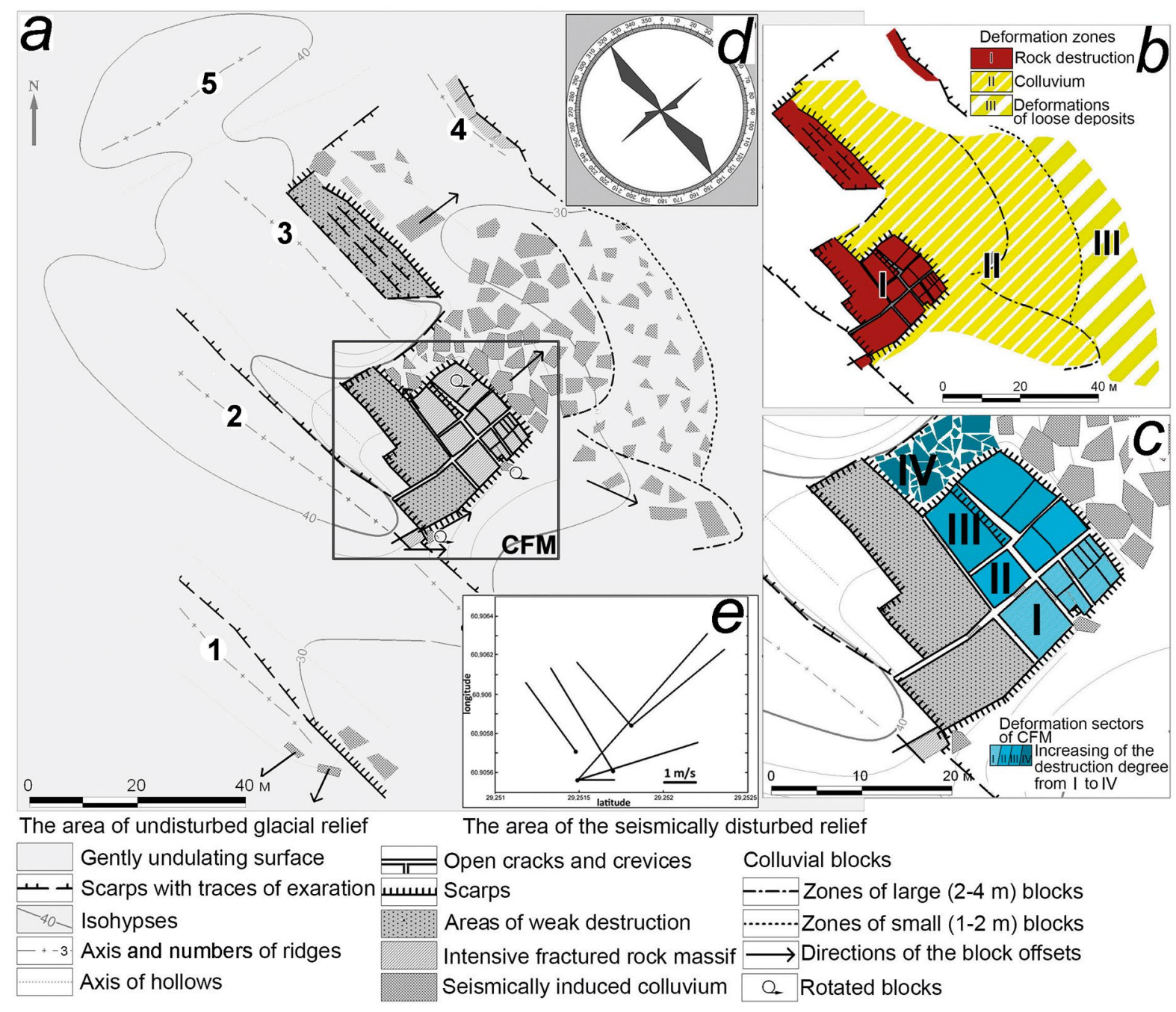

Figure 2. a) Sketch map of the site with the complex of seismogenic deformations (explanation in the text). b) Zones of seismogenic deformation. c) Sectors of CFM (explanation in the text). d) Main orientations of cracks and crevasses in massif. e) Main directions of block displacements with estimates of movement velocities.

small lateral displacements (up to $10 \mathrm{~cm}$, Fig. 3 , sector I), to the commonly occurring lateral and vertical displacements whose planes deviate from the vertical and which involve horizontal rotation in the middle (Fig. 3, sectors II and III), and finally to complete disintegration (sector IV) on contact with the intact rock hill. In sector IV the CFM is a hash of crushed and displaced rock blocks ranging in size between 0.5 and 3-4 m, or even more (Fig. 3a). Counter-clockwise rotation of blocks can be seen along the outer NE wall of the CFM (Fig. 3b).
The orientation of the blocks varies from Az. $320^{\circ}$ (sector I) to $310^{\circ}$ (sector II) and $300-305^{\circ}$ (sector III).

The vertical segmentation of the massif. Viewed in a vertical cross-section, an intensification of deformation (displacements of blocks and the degree of destruction, the number and size of cracks) can be observed from the upper to the lower depth levels. Higher up, the width of intrablock cracks varies from a few centimetres (sector I) to a few tens of centimetres (III), but lower down, the horizontal 


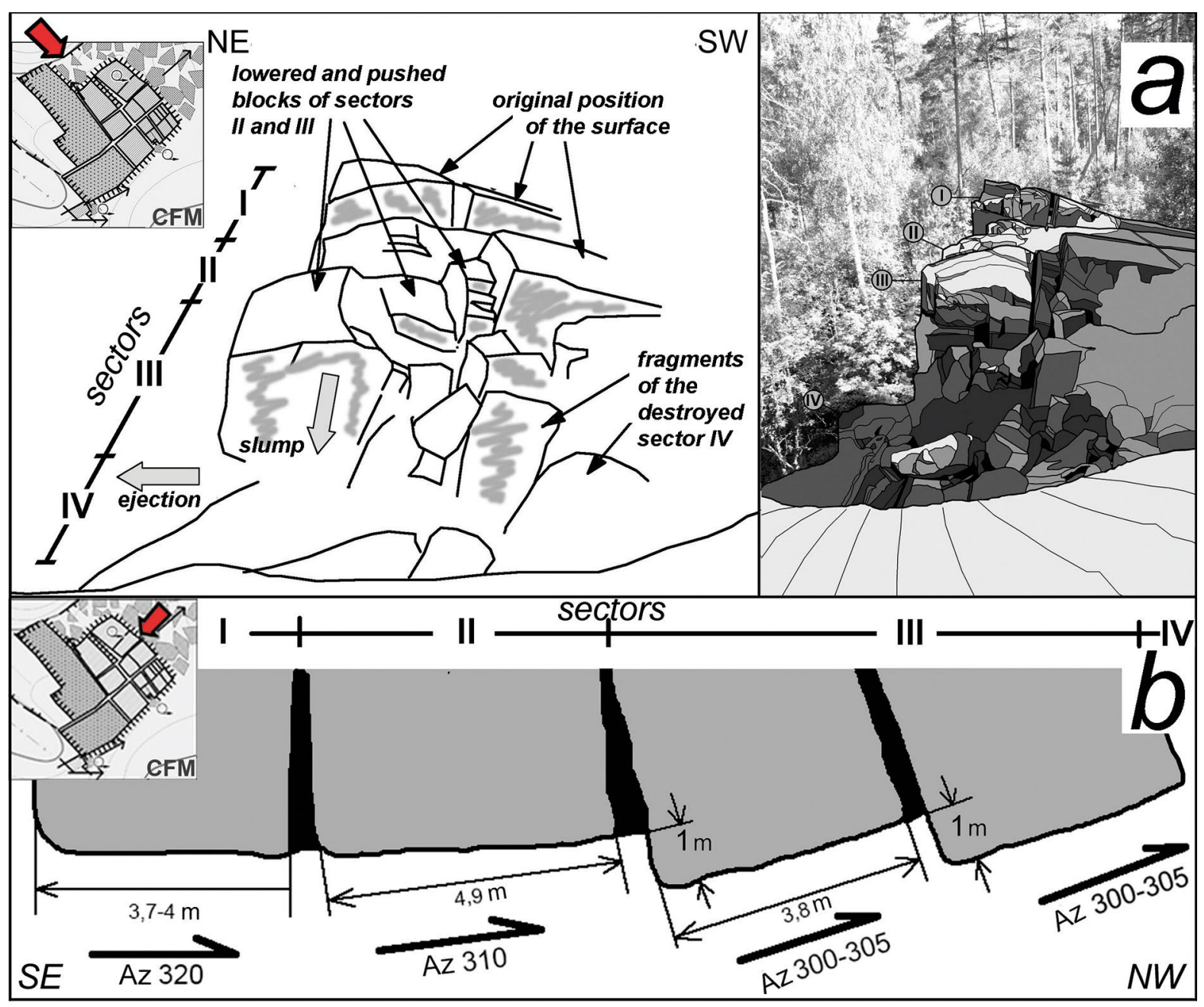

Figure 3. Lateral structure of CFM. a) A view of the fractured part of the rock massive with different zones of destruction (I-IV) from NW to SE (left) and a sketch of block subsidence in sectors II and III due to the fragmentation and destruction of the underlying depth levels (right). b) Rotation of blocks counter-clockwise along the outer NE wall of the CFM. Red arrow shows the location of the inset within CFM.

offset of large blocks up to $\geq 1 \mathrm{~m}$ is obvious. The crack width increases both in the NW direction (Fig. 4a) and in the NE direction (Fig. 4b). The interlayers of fragmented rocks were discovered between large blocks and at the base of CFM; these layers can be interpreted as zones of detachment (Fig. 4b, c).

\subsection{Earthquake-induced gravitational and vibrational deformation in rocks}

We found several locations near CFM where the postglacial rock surfaces are deformed. They presumably are large earthquake-induced gravitational (block landslides and debris) and vibrational (fragmentation and slippage) phenomena occurring both in mass movements and as displacements of individual blocks. 


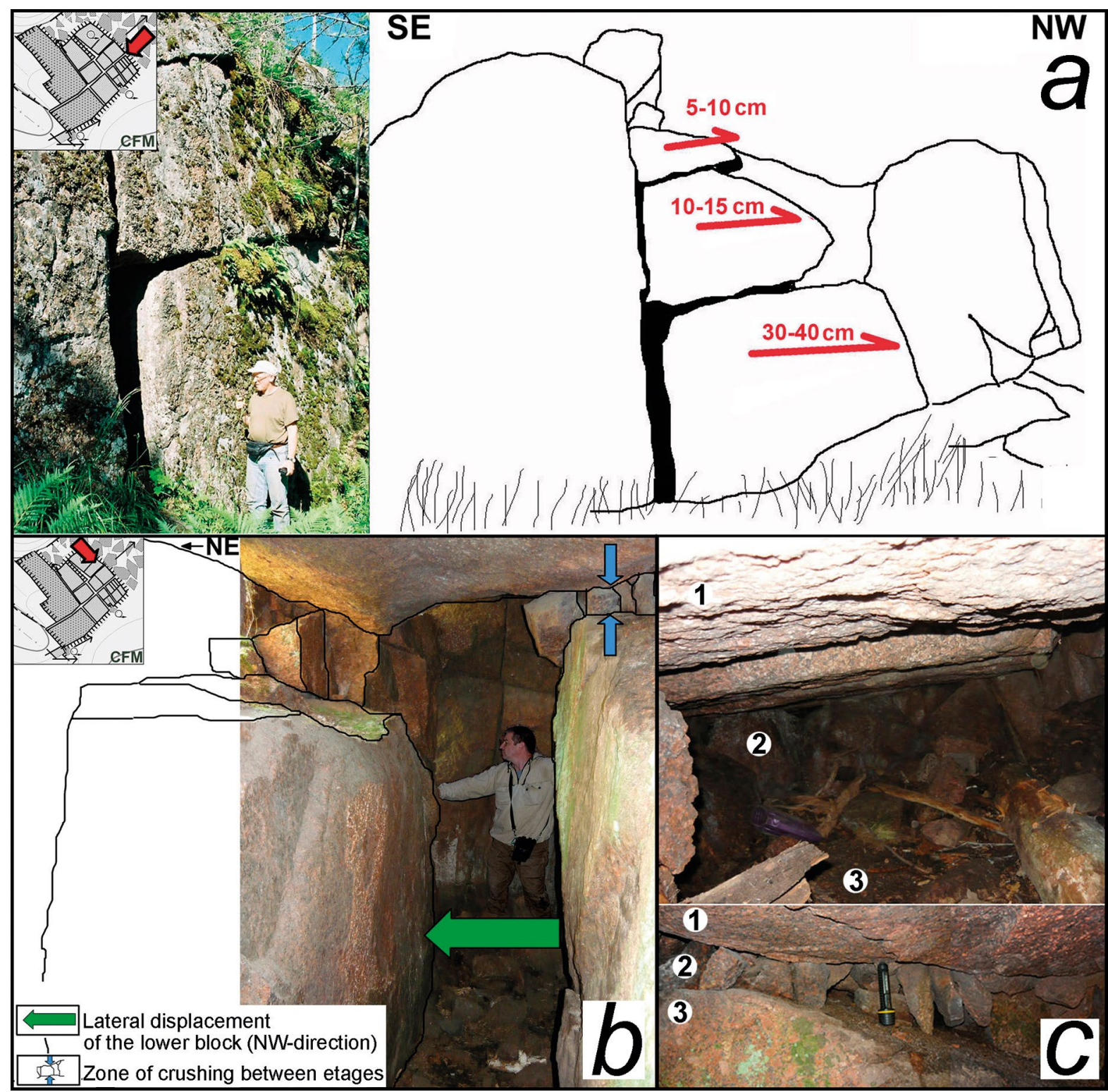

Figure 4. The vertical structure of CFM. a) Tiered moving blocks in the NW direction: the lower blocks show more displacement compared with the top blocks. b) Inner cavity of CFM parallel to outer NE wall. c) Horizontal zones of crushing at the bottom of the massif (top) and between depth levels (bottom): 1 - the top block; 2 - the zones of crushing and horizontal sliding; 3 - the lower block.

An earthquake-induced rock-fall produced a wide colluvial cover on the gentle slope. It extends up to 33-35 m to NE from CFM. Many blocks are as large as $4 \mathrm{~m}$ across, occasionally reaching 5-7 $\mathrm{m}$. This colluvial cover must be categorized as seismogenic, because the rock-fall scarp over it has a height of 7-9 $\mathrm{m}$, and the inclination of the adjacent foothill does not exceed $5-7^{\circ}$. Thus, it is difficult to explain the scatter of coarse blocky material to distances over $30 \mathrm{~m}$ without an additional strong horizontal impact. There are two distinct parts within the colluvial cover: the distal part with blocks of up to $1 \mathrm{~m}$ extends up to a maximum distance of $33-35 \mathrm{~m}$ to NE from the CFM and the proximal 


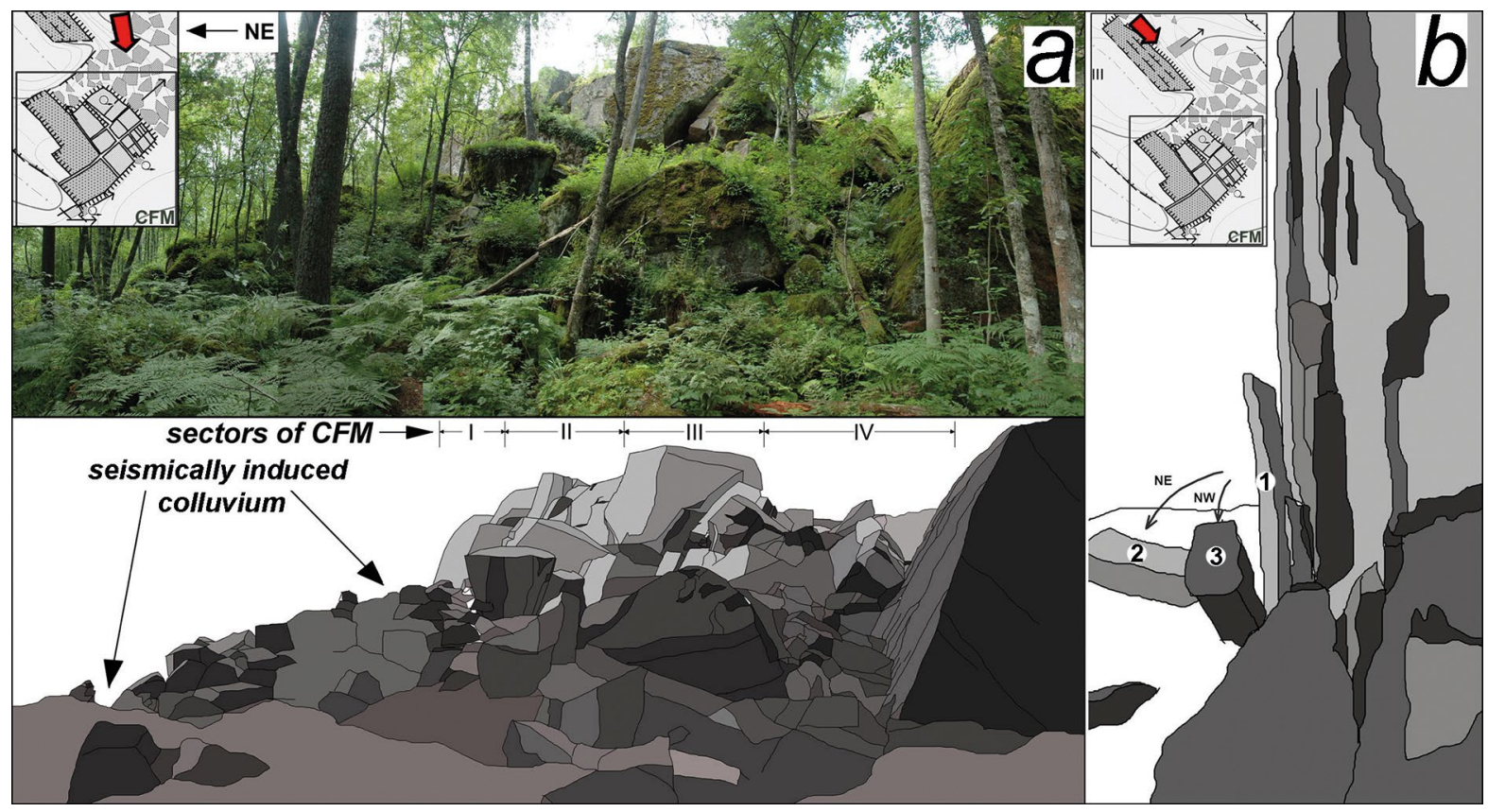

Figure 5. Seismically induced gravitational deformation. a) Seismically induced colluvial cover: photo (upper part) and a sketch (lower part). b) Cleavage of plates, which tilted to different degrees in the NE direction from the massif (blocks 1 and 2) and in the NW direction along the scarp (block 3).

part of the cover with blocks of up to $4 \mathrm{~m}$ in diameter, some reaching 5-7 $\mathrm{m}$. This part consists of two lobes. One of these is a wide (up to $35 \mathrm{~m}$ ) plume laterally extending NE to a distance of up to 20 $22 \mathrm{~m}$ (Fig. 2, 5a). The other lobe is elongate towards $\mathrm{SE}$ and is as long as $40 \mathrm{~m}$.

Another type of seismically induced gravitational deformation is cleavage and tilt of vertical flat blocks in the lower part of the scarp adjacent to the NW part of CFM. Here we observe the splitting of a large block $0.6-0.8 \mathrm{~m}$ thick, $5-7 \mathrm{~m}$ wide, and 4-6 $\mathrm{m}$ high. The block is tilted with respect to the scarp from a nearly vertical position into a $3-7^{\circ}$ overhang (Fig. 5b, block 1). Some of the plates are dipping NW along the scarp (Fig. 5b, block 3). One of the flat blocks $(8.0 \times 5.0 \times 1.0 \mathrm{~m})$ lies at the foot of the slope (Fig. 5b, block 2). It was thrown off from the CFM in a NE direction during the fall, judging by the distance between the proximal part of the plate and the base of a rocky ledge, that is $2-3$ times the plate thickness.
A presumably vibratory fragmentation of rock on horizontal surfaces with the formation of metersized blocks were also observed on the crests of ridges ( 1 and 4 in Fig. $2 a$ ).

It is noteworthy that the directions of the block displacements, which we have detected from seismically induced gravitational deformations, agree with those observed within the CFM massif.

\subsection{Soft-sediment deformations}

Soft-sediment deformation features were unearthed adjacent to CFM in a few pits (Fig. 6a). We found deformations of several types, all of which were encountered in pit N1 (Fig. 6b, c). The first type represents parallel folding that occurs in varved clays with amplitudes up to $0.1-0.2 \mathrm{~m}$ and wavelengths up to $0.4-0.6 \mathrm{~m}$. The second type includes small folds complicated by micro thrust faults that are characteristic for the upper half of the varved 


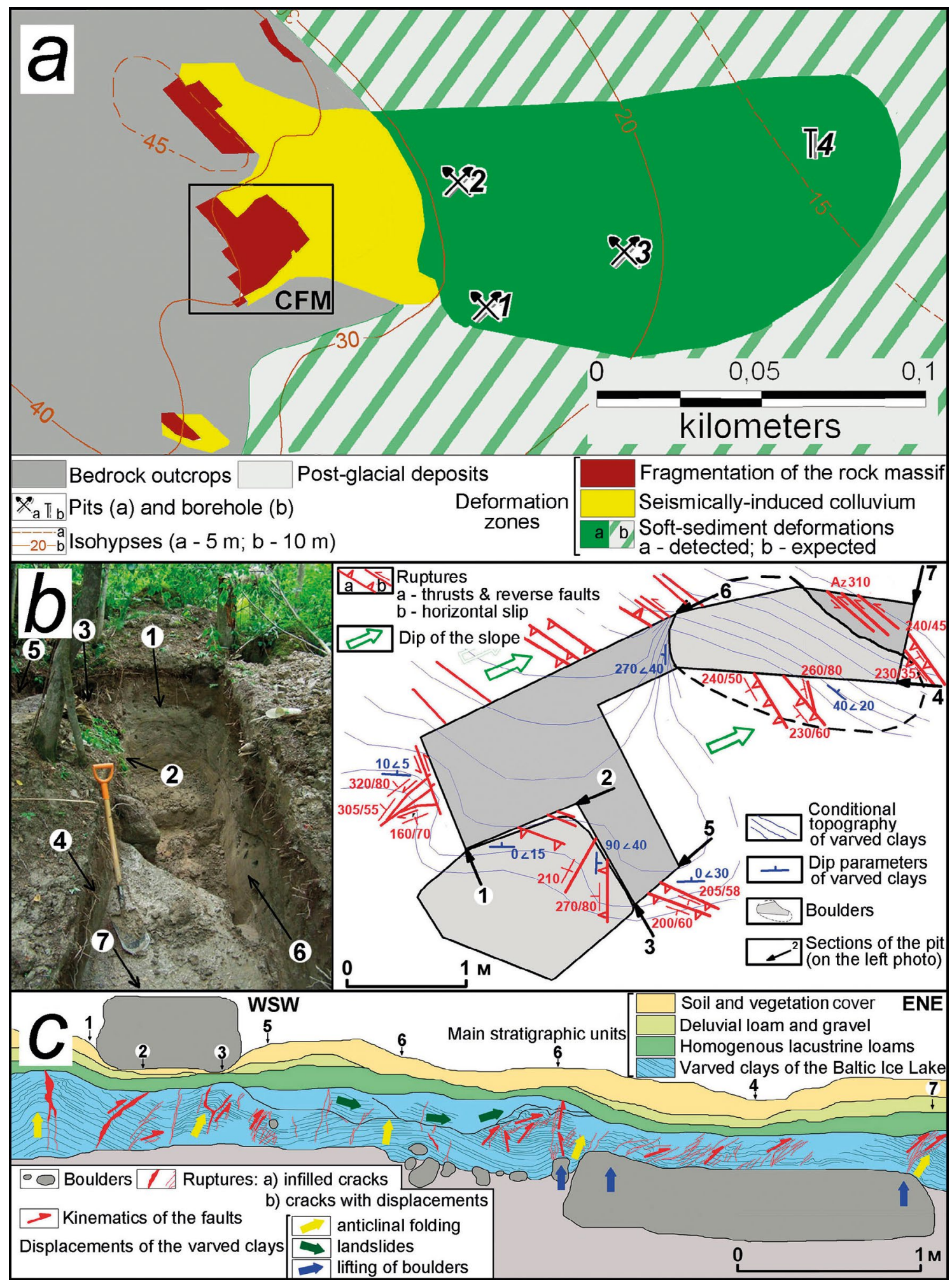

Figure 6. Soft-sediment deformation features near CFM. a) A sketch map showing the distribution of deformations of various types. b) A sketch of pit 1. c) A generalized cross-section of pit 1. 


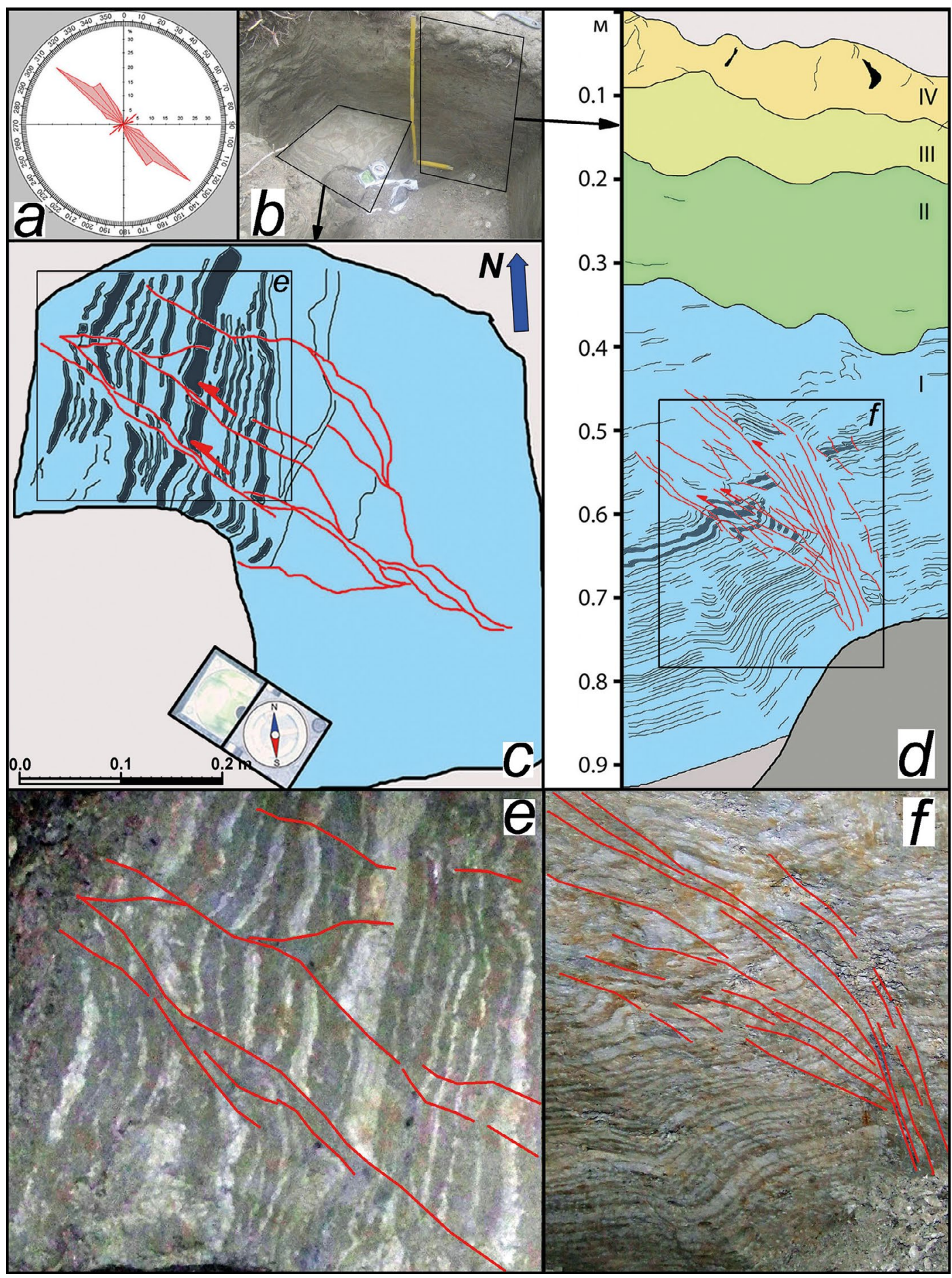

Figure 7. The main kinematic types of ruptures in soft sediments. a) Directions of cracks in different parts of the pit based on 31 measurements. b) A view of cross-section 7 (Fig. 6b,c) and the bottom of the pit in the eastern part. c) A horizontal view with strike slip faults (left) along NW striking cracks. d) A vertical view (cross-section 7, Fig. 6b,c). Reverse faults and folds. e) A fragment of horizontal cross-section, view c (photo). f) A fragment of cross-section 7, view d (photo). Main stratigraphic units: I varved clays of the Baltic Ice Lake; II homogeneous basin (lacustrine) silt; III deluvial (defluction) silt with gravel; IV soil and vegetation cover. 
clay layer. The third type includes wedge-shaped branched cracks, which are interconnected with the folds. The fourth type includes narrow cracks intersecting the entire layer of the varved clays with vertical (occasionally reaching an overthrust character) and horizontal shear displacements.

A typical cross-section consists of a layer of varved clays with a thickness of 1-1.5 m overlying a rock base. This layer is typically overlain by a homogeneous (unstratified) layer of basin loams $-0.5 \mathrm{~m}$ thick with deluvial (defluction) deposits in the upper part of the layer (Fig. 6c). The bestexpressed deformation features are preserved in the varved clays where there are numerous compressive features, including folds with amplitudes of few tens of centimetres, micro folds with amplitudes below $1 \mathrm{~cm}$, and rupture structures (reverse micro faults, normal faults, shears, and cracks filled by homogeneous sands). The overlying layer of homogeneous clay contains few landslides.

The orientation of cracks has two main directions: NW $\left(310-320^{\circ}\right)$ and NE $\left(35-55^{\circ}\right)$ with an absolute dominance of the former direction (Fig. 7a). These cracks have two main kinematic types: strike slip (left-lateral) and overthrusts, which can be well traced in the horizontal and vertical sections of pit N 1 (Fig. 7b, c, d).

Examination of folding and rupturing deformation features suggests a hypothesis that two different events took place here. The one can be attributed to the formation of folds (followed by the generation of wedge-shaped cracks in subaqueous conditions), a slide in the roof of the varved clays (coupled with the low-angle thrusts in its front side), low-angle thrusts over the sub-horizontal flat block, and a tightening of the belt layers up to the borders of the plate. The other event produced thin cracks with horizontal displacements, and reverse faults of other orientations that occurred under subaerial conditions. We can approximately estimate the time spans for these events. The first event occurred in the last stage of the Baltic Ice Lake lasting from $14.0 \mathrm{cal}$. kyr BP (12.0 14C kyr BP (Björk, 1995)) to $11590 \pm 100$ cal. yr BP (Saarnisto \& Saarinen, 2001) or 11560 cal. yr BP (Andrén et al., 2002). The time of the second event can be inferred from the data obtained from a borehole drilled in the middle of an adjacent lowland whose absolute height is approximately $15 \mathrm{~m}$ (Fig. 6a). The cross-section of this borehole includes four units (from top to bottom): silt with peat (to a depth of $0.3 \mathrm{~m}$ ), homogeneous silt (to $1.1 \mathrm{~m}$ ), sapropel (to $2.2 \mathrm{~m}$ ), and varved clays (to $2.7 \mathrm{~m}$ ) (Shvarev et al., 2017). Varved clays are the same as were found in pit 1. These also involve intensive deformation. The age of the sapropel bottom part was estimated as $7411 \pm 11014 \mathrm{C}$ yr BP (8.3 cal. kyr BP) (Subetto et al., 2017), hence this can be the upper time limit for the second event, with the time span for it lying between $\sim 11.5 \mathrm{cal}$. kyr and $8.3 \mathrm{cal}$. kyr BP.

The spatial character and the timing (sequence) of soft-sediment deformations allows us to correlate them with the first and second events as determined from the observed displacements. The third event deserves to be a topic of a separate publication. Here, within the framework of this paper, the authors are able to inform only a rough determination of the age of the third event. According to three dates ${ }^{14} \mathrm{C}$ from subsurface loose deposits, two of them on the north-east periphery of CFM and one in $2.7 \mathrm{~km}$ apart at the "Inostrantsevs' rocky outcrop", the last recognizable event had occurred about 1 kyr ago.

\subsection{Intensities and magnitudes of paleo-earthquakes}

The estimation of probable parameters of seismic events was carried out by two approaches, namely using the ESI-2007 scale (Michetti et al., 2007) and the method based on the examination of displacements of rock blocks from their initial positions (Rodkin et al., 2012). Thus, the movement of blocks along a sub-horizontal surface can be described by a simple model of the inertial displacement of a block mass $\mathrm{M}$ at distance $\mathrm{L}$ resulting from a seismic impact. The kinetic energy of the block $\mathrm{E}=\mathrm{MV}^{2} / 2$ is assumed to be equal to the work $\mathrm{fL}$ done by the friction force $\mathrm{f}=\mathrm{kgM}$ when moving over a distance $L$, with $k$ being the coefficient of friction (the experimental values for 
the coefficient of friction in rocks give values of $\mathrm{k}$ between 0.6 and 1.0). Hence the particle velocity $\mathrm{V}$ in a seismic wave can be roughly estimated as $\mathrm{V}=\sqrt{ }(2 \mathrm{kgL})$. Measurements and estimates of the directions and particle velocities $\mathrm{V}$ for different specimens showed the predominance of two directions, NE and NW, and typical values of $\mathrm{V}$ approximately 4 and $3 \mathrm{~m} / \mathrm{s}$ for the $\mathrm{NE}$ and NW directions, respectively (Fig. 2d). The values $\mathrm{V} \approx 2-4 \mathrm{~m} / \mathrm{s}$ could be generated by earthquakes with magnitudes of $-7.0-7.5$, if the responsible fault was at a distance of 5-7 km. If the fault was in the CFM itself, the magnitude could be lower, - 5.5-6 (Nikonov et al., 2014). The magnitude of the third event could be much less, about $5.5 \pm 0.5$.

\section{Discussion}

We infer rapid motion (i.e., an earthquake) to have been the cause of the observed deformation for the following reasons. Firstly, the displacements took place after the deglaciation of the area (very fresh scarps, an absence of glacial or glaciofluvial deposits inside the massive), so the deformation has no glacial origin. Secondly, the block movements were horizontal with a minor vertical component, and with greater displacements at the lower depth levels, hence these deformations have no gravitational origin. Thirdly, the width of the crevices (more than $1 \mathrm{~m}$ ) and the open system of cracks with free drainage show that the deformations did not result from rock weathering or geo-cryologic processes. Fourthly, the displacement in CFM (at the time of the second event) was directed along the ridge from the open space to the undisturbed massif. The degree of deformation (block destruction) increased in this direction due to the impact on the undisturbed massif.

A similar crushing of rock massifs, displacements of large blocks or other natural or artificial objects were observed in recent strong $\left(\mathrm{I}_{0}>\right.$ VII-VIII) earthquakes. An analysis of such events coupled with the comparison of paleo-earthquakes and effects of large-yield explosions have allowed us to develop a new approach to the evaluation of earthquake parameters using typical models of displacement (Rodkin et al., 2012). Large blocks can move at velocities over $1-2 \mathrm{~m} / \mathrm{s}$. Values such as these were estimated from the measurements of displacements of blocks in our case (Fig. 2e).

The three phases of deformation in the massif and the two phases in the adjacent sediments can be interpreted as connected with the three different seismic impulses oriented in NE, NW and NE directions, respectively. The difference in the kinematic parameters for the two first seismic impulses is supported by a special tectonophysical study of cracks in the massif (Nikonov et al., 2014). Our area of study has several features resembling those of the "Boda cave" in Sweden (Mörner et al., 2003). The occurrence of several strong earthquakes during the Late- and Post-Glacial times is the most important event in both of these cases. Similar objects were also described in Russian Karelia (Lukashov, 1995). One of the most interesting objects on the top of Mount Vottovaara was found earlier (Demidov et al., 1998). It was studied recently in detail (Shvarev \& Rodkin, 2018). Here the lateral displacements of blocks up to 7-8 meters across reached a few meters.

Another question is the origin of the softsediment deformations. We aprove that the main evidence to argue for a seismic origin consists from the combination of thrust faults and strike slip faults, which show similar characteristics, and which are closely similar to the orientation and kinematics of block displacements in rocks. Note that these parameters are not connected with slope processes, because the strike-slip and thrust faults are oriented both along and diagonally to the slope. We can see quite definite differences in the soft-sediment deformations: low-angle folds, which are associated with the first event and are discordantly traversed by the ruptures that are associated with the second event. 


\section{Conclusions}

Visual inspection and measurements of deformation features in rock and sediments allow us to identify three strong earthquakes that occurred during the Holocene. The result of our study is to determine the sequence and main parameters of deformation events:

1. The NE impulse. The rock massif was split into large blocks. The revelation of NW and NE cracks and displacement of the CFM lower depth levels toward NE happened; the collapse of the top layer over the knocked base occurred. The formation of earthquake-induced colluvium along the NE periphery of the destroyed the massif. The intensity of this event, whose main impulse was in the NE direction, can be estimated as I=IX. The time of this earthquake appears to be between 14.0 11.5 kyr BP.

2. The NW impulse. The detached blocks were shifted mainly to NW (impulse direction) and partly to SE (reverse movement). The NW displacement caused a complete destruction of the blocks adjoining the intact NW part of the massif. Partial closing of NE cracks occurred; seismically induced rockfall directed to SE happened. The intensity of the earthquake based on a NW displacement of $2 \mathrm{~m}$ can be estimated as I=IX. The earthquake occurred in the interval 11.5-8.3 kyr BP.

\section{References}

Afanasov, M.N. \& Shuldiner, V.I. (ed.), 1999. State geological map of Russian Federation. The Karelian Series. Scale 1: 200000. P-35-XXIX, XXX. St.-Petersburg. (In Russian)

Andrén, T., Lindeberg, G. \& Andrén, E., 2002. Evidence of the final drainage of the Baltic Ice Lake and the brackish phase of the Yoldia Sea in glacial varves from the Baltic Sea. Boreas 31, 226-238. https://doi.org/10.1080/030094802760260346.

Arkhangelsky, G., Gostintsev, V. B. \& Alexandrova, T. V. (eds.), 1974. Hypsometric map of the pre-Quaternary surface deposits. Scale 1: 500000. Comp. Report on the topic: geological mapping of scale 1: 500000, Leningrad. (In Russian)
3. During the last phase, some upper parts of the CFM were moved to NE again. The third strong earthquake knocked out the upper (only) parts of thin plates over the eastern edge of CFM to the east accompanied by some other, minor, seismically triggered deformations. It occurred considerably later than events 1 and 2, about $1 \mathrm{kyr}$ ago and had intensity of $\mathrm{I}=\mathrm{VII}-\mathrm{VIII}$.

Summing up the complex research we are in position to conclude, that the VFZ (its northern part at least) has to be regarded as inherited longlived active linear tectonic structure, which resulted from time to time destructive earthquakes during the Late- and Post-Glacial time.

\section{Acknowledgments}

The authors wish to thank colleagues Yu.S. Biske, A.V. Marinin, S.B. Nikolaeva, L.A. Sim, Yu.I. Systra, N.E. Zaretskaya, and D.A. Subetto for taking part in field work in various years. We thank Dr. Christoph Grützner and Dr. Jussi Mattila for careful analysis, valuable comments and suggestions. The research was carried out under research topics of IPE RAS (0144-2014-0097), IG RAS (0148-20180013) and GIN RAS (0135-2016-0012). The work was partly supported by the Russian Foundation for Basic Research, project 16-05-00727 A.

Björck, S., 1995. A review of the history of the Baltic Sea, 13.08.0 ka BP. Quaternary International 27, 19-40. https://doi.org/10.1016/1040-6182(94)00057-c

Bungum, H. \& Lindholm, C., 1997. Seismo- and neotectonics in Finnmark, Kola Peninsula and the Southern Barents Sea. Pt. 2. Seismological analysis and seismotectonics. Tectonophysics 270, 15-28. https://doi.org/10.1016/s0040-1951(96)00139-4.

Demidov, I.N., Lukashov, A.D., Lavrova, N.B., Shelekhova, T.S. \& Vyahirev, S.A., 1998. Paleoecology and paleoseismology of the Mt. Vottovaara area (West Karelia) in the late glacial and postglacial time, (Paleoclimates and Evolution of Paleogeographic Environments 
during the Geological History of the Earth: Abstracts of International Symposium Reports), Petrozavodsk, Russia, pp. 28-30. (in Russian)

Inostrantsev, A.A., 1870. Geognosticheskoye stroyenie zapadnogo berega Ladozhskogo ozera. S geognosticheskoyu kartoyu. Geological structure of the western shore of Ladoga Lake. With geological map. In: Materiali po geologii Rossii. Izdaniye Imperatorskogo S.-Peterburgskago Mineralogicheskago Obshchestva. Tom II. Sankt Peterburg, pp. 151-208. (In Russian)

Kuivamäki, A., Vuorela, P. \& Paananen, M., 1998. Indications of postglacial and recent bedrock movements in Finland and Russian Karelia. Geological Survey of Finland, Nuclear Waste Disposal Research, Report YST-99, 92 p.

Kujansuu, R., 1964. Nuorista sirroksista Lapissa. Summary: recent faults in Lapland. Geologi 16, 30-36.

Kukkonen, I.T., Ask, M.V.S. \& Olesen, O., 2011. Postglacial Fault Drilling in Northern Europe: Workshop in Skokloster, Sweden. Sci. Dril., 11, 56-59. https://doi.org/10.2204/iodp.sd.11.08.2011.

Lagerbäck, R. \& Sundh, M., 2008. Early Holocene faulting and paleoseismicity in northern Sweden. SGU Research Paper C836, 80 p.

Legkova, V.G. \& Mojaev B.N., 1977. Geomorphology of Karelia and the Kola Peninsula. Leningrad: Nedra, 183 C. (In Russian)

Lukashov, A.D., 1995. Paleoseismotectonics in the northern part of lake Onega (Zaonezhsky peninsula, Russian Karelia). Geological Survey of Finland. Nuclear Waste Disposal Research Report Yst-90,36 p.

Lukashov, A.D., 2004. "Recent geodynamics". In: Sharov N.V. (ed.), "Deep Structure and Seismicity of Karelian Region and Its Framing “, Petrozavodsk, p. 150. (in Russian)

Lundqvist, J. \& Lagerbäck, R., 1976. The Parvie fault: a lateglacial fault in the Precambrian of Swedish Lapland. Geologiska Föreningens I Stockholm Förhandlingar 98, 45-51. https://doi.org/10.1080/11035897609454337

Michetti, A.M., Esposito, E., Guerrieri, L., Porfido, S., Serva, L., Tatevossian, R., Vittori, E., Audemard, F., Azuma, T., Clague, J., Comerci, V., Gürpinar, A., Mc Calpin, J.,Mohammadioun, B., Mörner, N.A., Ota, Y. \& Roghozin, E., 2007. Intensity Scale ESI 2007. In: Guerrieri, L. \& Vittori, E. (eds.), Mem. Descr. Carta Geologica d'Italia, Servizio Geologico d'Italia, Dipartimento Difesa del Suolo, APAT, Rome, Italy, p. 74.

Mörner, N.-A., 1985. Paleoseismicity and geodynamics in Sweden. Tectonophysics 117, 139-153. https://doi.org/10.1016/0040-1951(85)90242-2.

Mörner, N.-A., 2003. Paleoseismicity of Sweden - a novel paradigm. P\&G-unit, Stockholm University, 320 p.

Mörner, N.-A., Audemard, F., Bronge, C., Dawson, S., Grant, D., Kvamsdal, O., Nikonov, A., Sidén, A., Sjöberg, R., Strandh, L., Sun, G., Tröften, P.E., Wigren, H. \& Zykov, D., 2003. The Hudiksvall area: The Boda Cave and its surroundings. The 9663 vBP paleoseismic event.
In: Mörner, N.-A. (ed.), Paleoseismicity of Sweden. Stockholm, pp. 29-224.

Niemelä, J., Ekman, I. \& Lukashov, A. (Eds.), 1993. Quaternary deposits of Finland and northwestern part of Russian Federation and their resources. Scale 1: 1000000. Geological Survey of Finland and Russian Academy of Science, Institute of Geology, Petrozawodsk.

Nikolaeva, S.B., 2006. Seismogenic Deformations in Early Holocene Sediments of the Pechenga River Terrace (Kola Peninsula). Doklady Earth Sciences 406, 4-7. https://doi.org/10.1134/s1028334x06010028.

Nikolaeva, S. B., Lavrova, N. B. \& Denisov, D. B., 2017. A Catastrophic Holocene Event in the Lake Bottom Sediments of the Kola Region (Northeastern Fennoscandian Shield). Doklady Earth Sciences 473, 308-312. https://doi.org/10.1134/s1028334x17030072.

Nikonov, A.A., 2008. Seismo-gravitational slope disturbances in the Northern Ladoga area. Sortavalsky local lore collection of papers. № 2. Petrozavodsk, pp. 7-25. (In Russian)

Nikonov, A.A., 2012. Seismodeformations in Late Holocene Estuary Deposits in the Central Part of St. Petersburg. Doklady Earth Sciences 443, 326-329. https://doi.org/10.1134/s1028334x1203018x.

Nikonov, A. A. \& Shvarev, S. V., 2015. Seismolineaments and destructive earthquakes in the Russian part of the Baltic shield: new solutions for the past 13 thousand years. Proc. of Intern. Conf. "Geological-geophysical environment and diverse manifestations of seismic activity" on 23-25 September 2015, pp. 243-251. (in Russian)

Nikonov, A.A. \& Zykov, D.S., 1996. Paleoseismodeformations in Eastern Fennoscandia. Seismology in Europe. XXV General Assembly. Sept. 9-10, 1996. Reykjavik, Iceland, pp. 122-127.

Nikonov, A.A., Shvarev, S.V., Sim, L.A., Rodkin, M.V., Biske, Yu.S. \& Marinin, A.V., 2011. Seismotectonics, seismodeformations and paleo-earthquakes in the keyarea "Inostrantsev Caves": the experience of detailed investigations on the Fennoscandian shield. Proceed. Russ. Conf. "Problems of seismotectonics", Moscow, pp. 384-388. (In Russian)

Nikonov, A.A., Shvarev, S.V., Sim, L.A., Rodkin, M.V., Biske, Yu.S., \& Marinin, A.V., 2014. Paleoseismodeformations of hard rocks in the Karelian isthmus. Doklady Earth Sciences 457, 1008-1013. https://doi.org/10.1134/s1028334x14080145.

Olesen, O., Henkel, H., Lile, O.B., Mauring, E., and Rønning, J.S., 1992. Geophysical investigations of the Stuoragurra postglacial fault, Finnmark, northerh Norway. Journal of Applied Geophysics 29, 95-118. https://doi.org/10.1016/0926-9851(92)90001-2

Rodkin, M. V., Nikonov, A. A. \& Shvarev, S. V., 2012. Evaluation of quantities of seismic effects on deformations and displacements in rock massifs. Geodynamics \& Tectonophysics 3, 203-237. (In Russian) https://doi.org/10.5800/gt-2012-3-3-0072. 
Saarnisto, M. \& Saarinen, T., 2001. Deglaciation chronology of the Scandinavian Ice Sheet from the Lake Onega Basin to the Salpausselkä End Moraines. Global Planetary Change 31,387-405. https://doi.org/10.1016/s0921-8181(01)00131-x.

Shvarev, S.V. \& Rodkin, M.V., 2018. Structural Position and Parameters of the Paleoearthquakes in the Area of Vottovaara Mountain (Middle Karelia, Eastern Part of the Fennoscandian Shield). Seismic Instruments 54, 199218.

https://doi.org/10.3103/S0747923918020093.

Shvarev, S. V., Subetto, D. A., Nikonov, A. A., Zaretskaja, N.E., Poleshchuk, A.V. \& Potakhin, M.S., 2017. On the connection of catastrophic changes in the hydrographic network of the Karelian Isthmus in the Holocene with strong earthquakes. In: Gerasimov, D. V. (ed.), Cultural processes in the Circum-Baltic space in the early and middle Holocene: Reports of the international scientific conference dedicated to the 70th anniversary of
V. I. Timofeev. St. Petersburg: the Kunstkamera, pp. 1721. (in Russian)

Sjöberg, R., 1994. Bedrock Caves and Fractured Rock Surfaces in Sweden: Occurrence and Origin. PhD Thesis, Stockholm University, Stockholm, Vol. 7, 110 p.

Subetto, D.A., Shvarev, S.V., Nikonov, A.A., Zaretskaja, N.E., Poleshchuk, A.V. \& Potakhin, M.S., 2017. Catastrophic changes of the Karelian Isthmus hydrographic network in the Late Glacial - Holocene: palaeoseismological origin. In: Sarala, P. \& Johansson, P. (eds.), From past to present - Late Pleistocene, last deglaciation and modern glaciers in the centre of northern Fennoscandia, Excursion guide and Abstracts. INQUA Peribaltic Working Group Meeting and Excursion 2017, 20-25 August 2017. Geological Survey of Finland, Rovaniemi, pp. 156-157.

Zykov, D.S., 2001. Modern geodynamics of the North Karelian zone (Baltic shield). GEOS (Transactions of GIN RAS; Vol. 534), 146 p. (in Russian) 